\title{
Investigations of Properties of Powdered Ferromagnetic Sorbents
}

\author{
Treijs J. ${ }^{1}$, Teirumnieks E. ${ }^{1}$ Mironovs $\mathrm{V}^{2}$, Lapkovskis $\mathrm{V} .{ }^{2}$, Shishkin A. ${ }^{2}$ \\ 1 - Rezeknes Augstskola (Rezekne Higher Education Institution), Atbrīvošanas Aleja 76, LV - \\ 4601, Rēzekne, Latvia, tel./fax:+371 64625167,e-mail: juristreijs@inbox.lv,edmunds@ru.lv \\ 2 - Riga Technical University, Azzenes Street 16/20, lab. 331, LV-1048, \\ Riga, Latvia, tel.:+37167089270 e-mail:viktors.mironovs@rtu.lv
}

\begin{abstract}
The paper examines possible application of certain disperse materials based on iron powders as ferromagnetic sorbents for collecting the oil products spilled on the water surface. Sorption ability is defined for the investigated ferromagnetic sorbents.
\end{abstract}

Keywords - oil absorbent, oil spill collection, ferromagnetic absorbent, ecology.

\section{INTRODUCTION}

The problem of water treatment from pollution by oil, oil products is becoming more and more topical. Accidents involving oil spills from large-capacity tankers and oil emission from bore wells at seas have begun to arise more often. Thus in April, 2010 there was accident on an oil platform of British Petroleum corporation. A large amount of oil was released into the Gulf of Mexico. The company spent huge numbers of forces and funds for cleaning of the Gulf, coast and compensation for pollution-made damages. In semi-closed water areas of harbours, in basins of the navigable rivers, the leakages of fuel, oils, unauthorized dumping of crude slop waters from passing and quayed ships are becoming material negative factors. Leakages of fuel from stationary capacities of oil depots, petrochemical productions, the large motor transportation enterprises, accidents on the oil pipelines are inevitably leading to pollution getting into soil, into underground waters, and with surface, thawed and storm water also into the river basins. Thus, the problem of elimination of pollution of the water surfaces with oil products is of a global nature and topical both for seas and oceans, as well as for streams and small rivers flowing inland of the continents.

There are various methods of water treatment from pollution by oil products [1]: mechanical, physical and chemical and biochemical one. Each group has its strengths and weaknesses, areas of concentration and total volume of pollution, in which these are the most effective. On a case-by-case basis it is necessary to apply complex and multistage technology of cleaning with a prevalence of one or other methods. However, papers [1,2] specify that only the use of sorbents allows to clear water from oil products to the highest degree of purity without introduction of secondary pollution.

Natural and artificial porous and other materials with the developed surface are applied as sorbents. They have to meet certain requirements: maximum available sorption capacity; buoyancy (in case of application by spraying over surface of the polluted water); wear resistance (in case of use in bulk filters), etc. There are data available about application of production waste of asbestos papers and cardboard as a sorbent for water purification from oil products [3]. Such sorbent allows performing its regeneration by thorough warming. There are widespread polymeric sorbents: granulated copolymer of styrene and divinylbenzene [4], which can be regenerated by solvents; polyurethane foam [5], which regeneration is conducted by extraction. The sorbent on the basis of hydrofobized basalt fibers is easily regenerated by extraction and burning of the remainder oil products [6]. Woodchips and sawdust applied as a sorbent and placed in pervious woven covers [7] can be utilized by burning with output of energy. Shortcoming of this sorbent is its fast turgescence owing to absorption of water and the loss of buoyancy. The granulated activated charcoal is one of the most widespread sorbents of a wide range of atmospheric and water pollution, naturally is also used in water purification from oil products [1, 2, 8, 9]. However, the absorbent carbon is one of the most expensive sorbents owing to what it is used, as a rule, at supplementary treatment of potable water. All the above described sorbents have one more common shortcoming: complicated collecting from a water surface after implementation of the process of sorption, which is possible only by mechanical means - scrapers, sediment pumps, etc. from the increased concentration zone limited to boom obstructions.

Allocation of magnetic properties to sorbents can ensure substantial increase of efficiency of their use since an opportunity appears to introduce sorbents into the environment subject to decontamination in the form of a disperse phase at a controlled surface of interphase contact and to remove from the environment by means of a physical method [10-16].

Possibility to use disperse ferromagnetic sorbents for collecting oils and other oil products poured on a water surface and at the bottom of a water body, was reviewed in papers [17-18]. Iron powders, crushed particles of mill scale, etc. were used as initial materials. Ferromagnetic 
sorbents based on iron powders have perfectly recommended themselves when cleaning plumage of the birds getting into oil spills in water bodies [19-20]. Papers [21-22] are describing the "Nefteklin" sorbent used for collecting oil spills from the water surface. Fibrous organic substances, such as lignin, soybean seed coats, waste of agricultural and woodworking production, are used as raw materials to obtain the "Nefteklin" sorbent. The base is crushed, then processed in a disperser, separated from solution and dried. Then ferromagnetic particles are added. Shortcoming of this sorbent is its turgescence owing to absorption of water and the loss of buoyancy

The problems entailing utilization of slime collected by sorbents, realization of possibility of regeneration of sorbents are presenting interest. Three main methods of regeneration of sorbents and utilization of the oil products collected thereby are known [2]: chemical (processing by solvents); low-temperature (processing by water vapour) and thermal (desorption of high-boiling organic compounds by steam-gas mixes). The first method is comparatively expensive and toxic therefore it is barely used and only in the event of small volumes of pollution of water by oil products. The second method is effective for extraction of low-molecular organic compounds. The third, thermal method is the most widespread one and used on commercial scale. Treatment of sorbent with slime in this method is possible in drum furnaces, multihearth furnaces and in furnaces with a boiling layer. According to data from literature [2], losses of a sorbent at thermal regeneration do not exceed $10 \%$, and sorption ability is restored at least 8-10 times and more.

Recently among processes of decomposition of organic compounds including slimes of oil products, polymeric waste, etc. increasing place is taken by pyrolysis thermal decomposition without air access. As a result of pyrolysis less complicated particles, molecules of simple organic compounds and ashes are formed from molecules of organic waste; the products of pyrolysis can be used as raw materials for chemical productions and fuel. Pyrolysis is one of the most important industrial methods for obtaining raw materials for petrochemical synthesis. Target product of pyrolysis - a gas rich in unsaturated hydrocarbons: ethylene, propylene, butadiene. On the basis of these hydrocarbons, polymers are obtained for production of plastics, synthetic fibers, synthetic rubbers and other major products.

This paper is focused on the possibility of application of some powder ferromagnetic sorbents for collecting of spillages in water.

\section{MATERIALS AND METHODS}

Powdery materials on the basis of iron were used as research materials, the majority from which are applied in production of constructional, tribotechnical and other materials. In particular we have selected iron powders of brands: ASC 100.29 - sprayed, used in production of constructional details by methods of powder metallurgy; MH 80.23 - reduced, spongy is used in production of self-lubricating sliding bearings; M20/80-19 with the lowered content of carbon and R-12 with lowered content of hydrogen, used in production of frictional products. All the powders are manufactured by Höganäs AB (Sweden). As well as the powder CMS represents waste from the filter in production of iron powders by the Höganäs $\mathrm{AB}$ (Certificate EN 10 204.3.1B), contains $94.1 \%$ of Fe, $0.6 \%$ of C.

Composite sorbent (CS) COMSOR developed jointly by the RTU and Rezekne Higher Education Institution was used as well. The technology of obtaining is described in the patent application under number P-12205 dated 28.12.2012. Its characteristics - increased buoyancy and at the same time magnetic properties (Fig. $1,2)$.

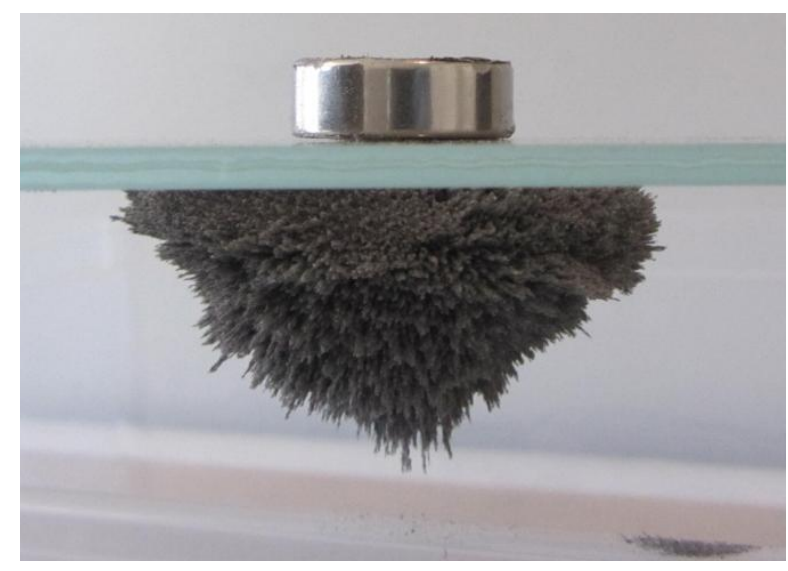

Fig. 1. CS retaining by a magnet

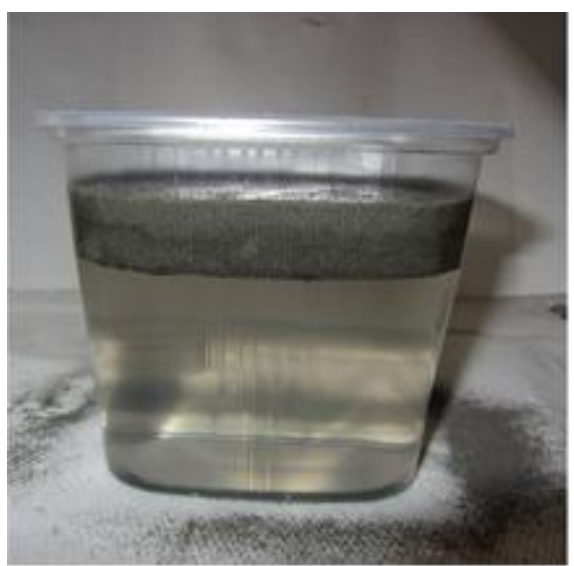

Fig. 2. CS retaining on a water surface

Specific surface of powders was determined on the SA 3100 analyzer made by "Beckman Coulter, Inc." company (USA). Morphology of the surface of particles was investigated on a MIRA scanning electronic microscope of high resolution made by "Tesla" company (Czech Republic). Bulk density, average size of particles and chemical composition of powders was taken from catalogues and accompanying documents of the manufacturers. For the analysis of sorption ability the TAD 17 transmission oil (GOST standard specification 23652-79) was used. The amount of the adsorbed oil was determined by weight of the previously weighed portion 
of a sorbent of each type after removal of a sorbent from the water surface on the MS 500 electronic scale with an accuracy of $0.1 \mathrm{~g}$.

The methods of the experiment included stages as follows: filling in a non-magnetic container of tap water to a fixed height (not less than $30 \mathrm{~mm}$; drawing on a water surface of transmission oil in the volume of $10 \mathrm{~g}$; holding not less than 2 minutes for formation of a stable film on a surface; drawing of a portion of the powder subject to investigation weighing $50 \mathrm{~g}$ on a film by means of spraying; holding during not less than 2 minutes for ensuring full value of collecting oil by sorbent particles; removal of particles with oil by means of constant magnet wrapped up by a polymeric film; separation of the polymeric film with particles of a sorbent and oil from the magnet and carrying out further research - weighing for assessment of absorbing ability.

\section{RESULTS AND DISCUSSION}

Some properties of iron-based powders are provided in the Table 1.

TABLE 1

PROPERTIES OF INVESTIGATED IRON-BASED POWDER MATERIALS

\begin{tabular}{|c|c|c|c|c|c|c|}
\hline \multirow{2}{*}{ Brand } & Manufacturer & $\begin{array}{c}\text { Bulk density } \\
\mathrm{g} / \mathrm{cm}^{3}\end{array}$ & $\begin{array}{c}\text { Average size of } \\
\text { particles, } \mu \mathrm{m}\end{array}$ & $\begin{array}{c}\text { Specific surface, } \\
\mathrm{m}^{2} / \mathrm{g}\end{array}$ & \multicolumn{2}{|c|}{ Element content, weight \% } \\
\cline { 5 - 7 } & Höganäs AB, Sweden & 1.56 & 250 & 0.159 & 92 & $\mathrm{C}$ \\
\hline M20/80-19 & Höganäs AB, Sweden & 2.98 & 50 & 0.287 & 99.9 & 0.23 \\
\hline R12 & Höganäs AB, Sweden & 1.35 & 280 & 0.225 & 98 & 0.2 \\
\hline CMS & Höganäs AB, Sweden & 2.6 & 20 & 0.315 & 94 & 0.6 \\
\hline $\begin{array}{c}\text { Composite sorbent } \\
\text { (COMSOR) }\end{array}$ & RTU & $0.6-0.8$ & 100 & 0.57 & N/D & N/D \\
\hline
\end{tabular}

Figures 3-6 are presenting the morphology of surfaces of particles of the investigated samples of disperse sorbents based on the powders of iron and composite sorbent.

Images displaying the surface of particles (Fig. 2-5) demonstrate that the majority of the investigated particles of iron powder have a developed porous form, being characterized by presence of a system of micro- and macro-pores extending from the surface deep into the particle (Fig. 2, 4). Composite material particles mainly possess a regular spherical form, however the specific surface of a composite sorbent is significantly higher (Table 1) due to considerably smaller density of particles.

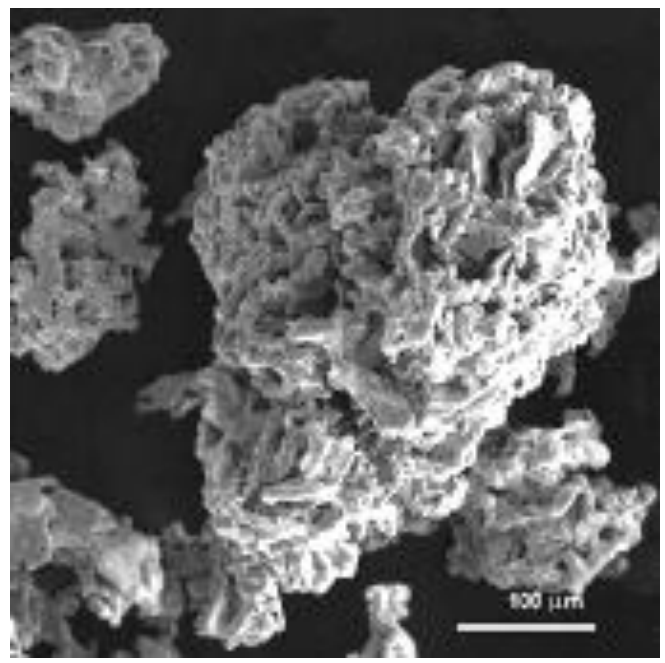

Fig.3. Morphology of the surface of particles of iron powder M20/80-19

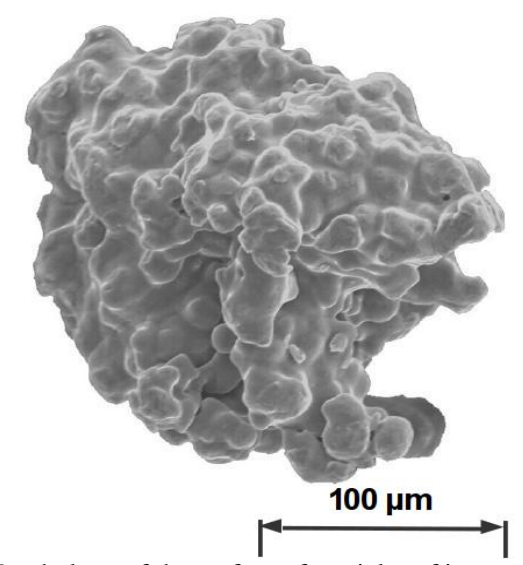

Fig. 4. Morphology of the surface of particles of iron powder ASC 100.29

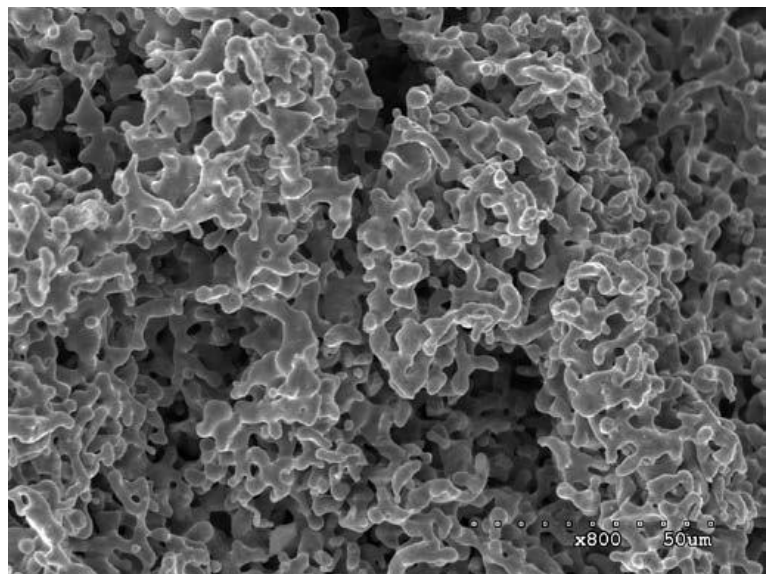

Fig.5. Morphology of the surface of particles of iron powder R12 


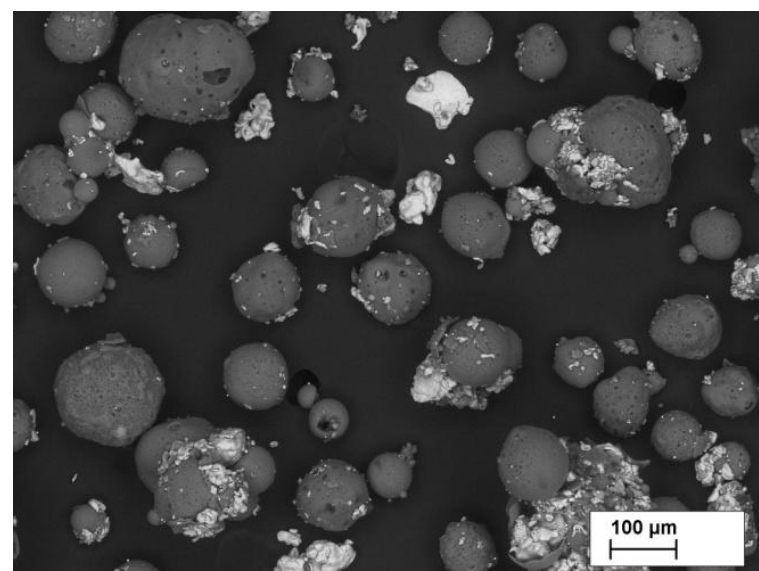

Fig. 6. Morphology of the surface of particles composite absorbent COMSOR

Results of research of the process of collecting oil from the water surface through using iron powder of the M20/80-19 brand are visually presented in Fig. 7, with use of COMSOR on Fig.8.

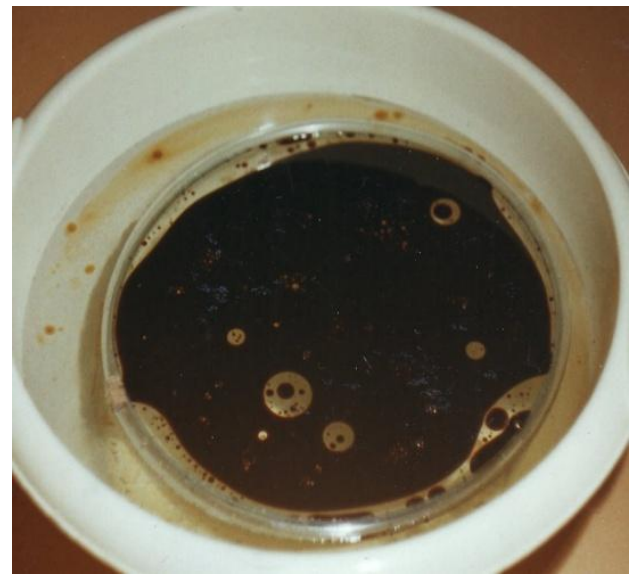

a

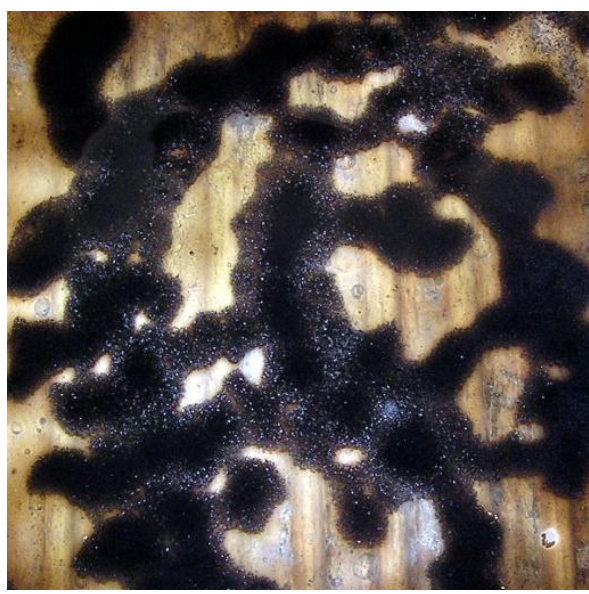

b
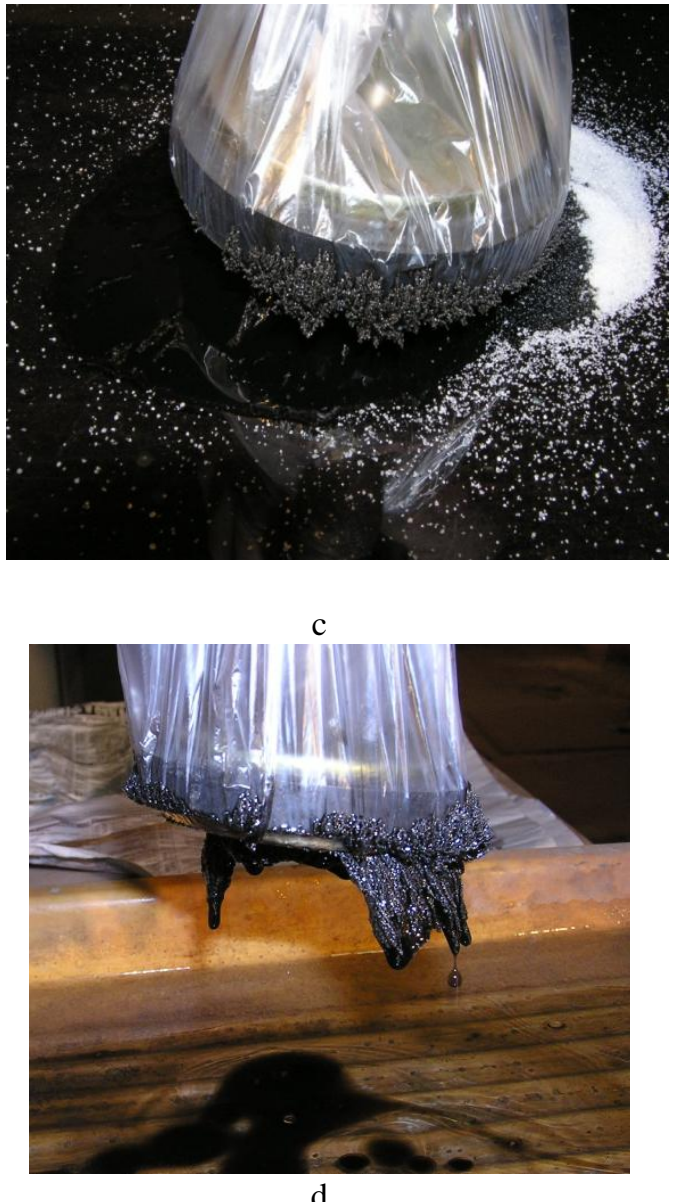

Fig. 7. Results of pilot studies of the process of collecting oil from a water surface using a powder M20/80-19: a) oil on a water surface: b) formation of the centres of coagulation; c) slime capture; d) slime evacuation

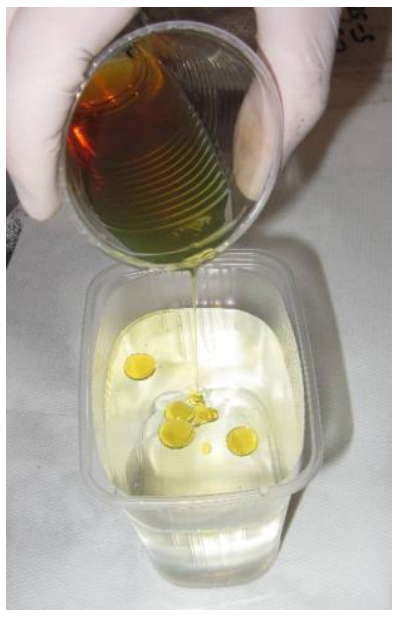

a

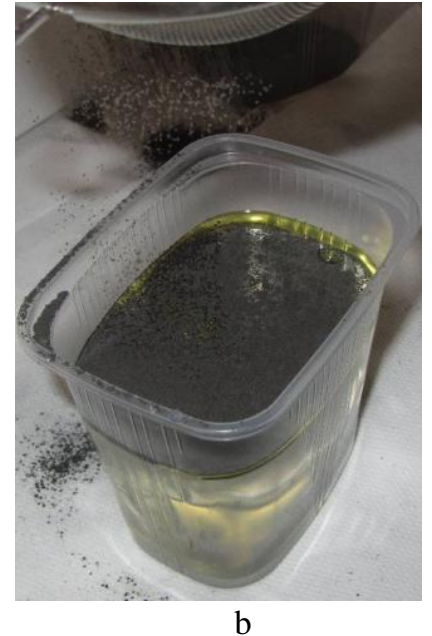

b 

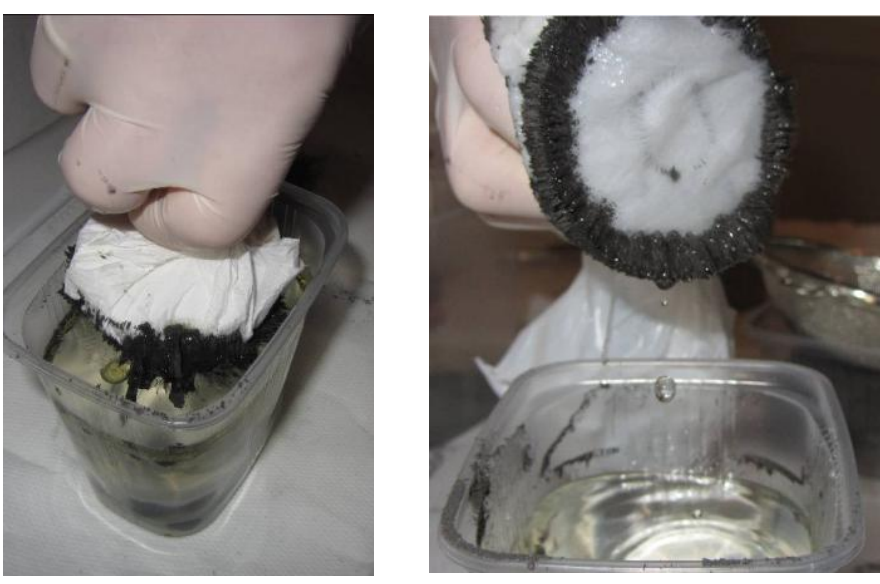

c

d

Fig. 8. Results of pilot studies of the process of collecting oil from the water surface using composite sorbent COMSOR: a) oil on the water surface: b) sorbent spreading over the oil film surface; c) slime capture; d) slime evacuation.

According to the experiment data it was established that at the expense of primary moistening of particles of the investigated powders, the capillarity and absorption phenomena, samples of sorbents based on iron powder can retain $10-22 \%$ (by weight) oils and up to $57 \% \%$ (by weight) using CS (Fig.9).

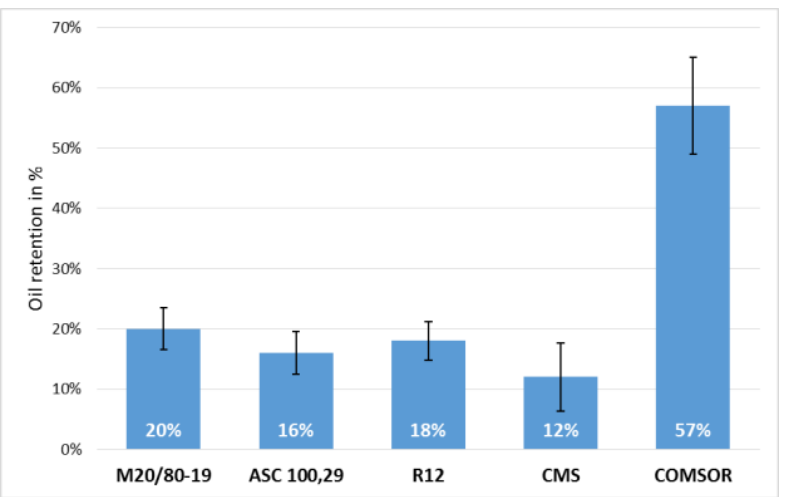

Fig. 9. Sorption ability of some iron-based powdered ferromagnetic sorbents on oil \%

As apparent from Fig. 9, CS COMSOR possesses the greatest sorption ability that is explained by features of the morphology of surfaces of their particles (Fig. 6), as well by extended specific surface. Analyzing the sorbent activity, it is possible to affirm that oil and water are retained on the developed surface of iron powder for two reasons:

1. Due to the influence of moistening ability of the external developed surface of the powder particles;

2 . Due to the expression of capillarity by the volume of spongy and porous particles (Fig. 2-4).

Thus, water is retained by internal pores of particles, and oil - by their entire external surface (Fig.11).

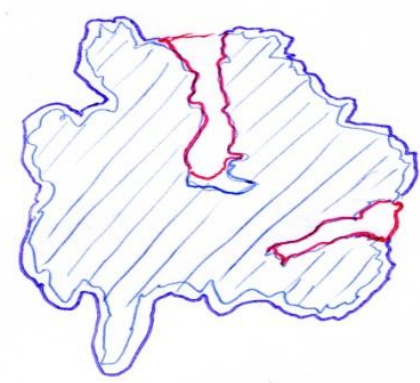

Fig. 11. Model of an iron powder particle $\mathrm{MH} 80.23$, moistened by water (inside pores) and oil (a double contour over entire external surface of particles)
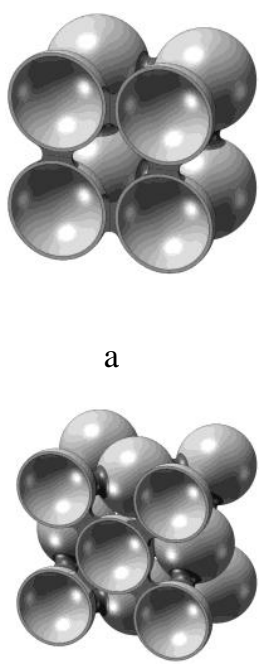

c

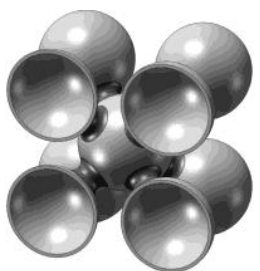

$\mathrm{b}$

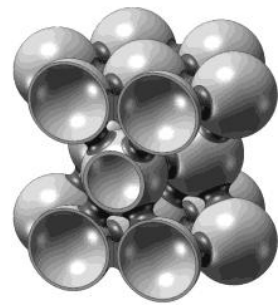

d
Fig 12. Simple topologies of spheres packaging: a) primitive cubic;

b) body-centred cubic; c) face-centred cubic; d) hexagonal

A strong increase of oil absorption by the COMSOR absorbent can be explained by the following hypothesis. Spherical objects in ideal conditions can stack together in 4 main packaging types - shown in Fig. 12. Such formations may possess manifold channels between particles, which in case of positive wetting force, can be filled up with liquids.

The particles are kept together by liquid bridges at their contact points in the pendular state. This situation requires that the saturation is low enough to let discrete binary bridges exist between the solid surfaces. Such a lensshaped ring of liquid causes adhesion due to the surface tension forces of the liquid/air interface and the hydrostatic suction pressure in the liquid bridge [24]. The capillary structure occurs when a granule is saturated. All the voids between the particles are filled with liquid and the surface liquid of the agglomerates is drawn back from the surface into the interior of the agglomerate. The particles are kept together in this configuration due to capillary suction at the liquid/air interface, which is now only at the agglomerate surface. 


\section{CONCLUSIONS}

1. A research has confirmed that ferromagnetic iron-based powder materials may be used as sorbents for spilled oil products.

2. The highest sorption ability was demonstrated by the synthesised COMSOR absorbent, which can be explained by morphology of Hoganas M20/80 iron powder particles and its surface structure.

3. A sorption ability of the iron-based sorbents is proved by means of experimental setup. The following mean oil sorption characteristics (by weight a sorbent material) have been obtained: $22 \%$ (for iron-based powders), and $57 \%$ (for COMSOR absorbent).

\section{REFERENCES}

[1] Ponomarev V.G., Ioakimis E.G., Mongate I.L. Oil Refinery Sewage Treatment. - M: Chemistry (in Russian - Пономарев В.Г., Иоакимис Э.Г., Монгайт И.Л. Очистка сточных вод нефтеперерабатывающих заводов. - М.: Химия), 1985. 256 pages.

[2] Kulubova L.I. Morozov S.V. Treatment of Oil Containing Sewage: Analyt. review. - Siberian Branch of the Russian Academy of Science. State Public Scientific Technical Library, Novosibirsk Institute of Organic Chemistry (in Russian Кулубова Л.И., Морозов С.В. Очистка нефтесодержащих сточных вод: Аналит. обзор. - СО РАН. ГПНТБ, НИОХ). Novosibirsk, 1992. - 72 pages.

[3] USSR Inventor's Certificate 1451099, IPC C 02 F 1/28. Method of purification of waters from oil products and oils. Mocharov V.M., Savitskaya P.V., Egorova O. A. et al. (in Russian - A.c. 1451099 СССР, МКИ С 02 F 1/28. Способ очистки вод от нефтепродуктов и масел. Мочаров В.М., Савицкая П.В., Егорова О.А. и др.).

[4] USSR Inventor's Certificate 1444307, IPC C 02 F 1/28, G 01 N30/08. Method of saturation of oil products from water environments. Senin A.N., Gorchakov V.D, Denisova M.V., et al. (in Russian - A.c. 1444307 СССР, МКИ С 02 F 1/28, G 01 N30/08. Способ концентрирования нефтепродуктов из водных сред. Сенин А.Н., Горчаков В.Д., Денисова М.В. и др.).

[5] USSR Inventor's Certificate 1452550, B 01 D 35/06; B 03 C 1/00. Method of sewage treatment. Belichenko Y.P., Bereza A.P., Rudin T.R. et al. (in Russian - A.c. 1452550 CCCP, B 01 D 35/06; В 03 C 1/00. Способ очистки сточных вод. Беличенко Ю.П., Береза А.П., Рудин Т.Р. и др.)

[6] Pavlik P.E., Bochmanov A.D. Sorbent for collecting oil and oil products from a water surface. 14th Mendeleev Congress on General and Applied Chemistry (in Russian - Павлик П.Е., Бочманов А.Д. Сорбент для сбора нефти и нефтепродуктов с поверхности воды. 14-й Менделеевский съезд по общей и прикладной химии). - Vol.2. - M, 1989, p.444.

[7] Pat. 4784773 USA, IPC C 02 F 1/40. Petroleum product absorption method and apparatus. Sandberg Fr.H.

[8] Tymoshenko M.N., Klemenko N.A. Application of activated charcoal in the water and sewage treatment technology. Chemistry and Technology of Water (in Russian - Тимошенко М.Н., Клеменко Н.А. Применение активных углей в технологии очистки воды и сточных вод. Химия и технология воды). 1990. - Vol.12, No. 8. - pp.727-738.

[9] Adsorption system. Water Eng. and Manag. - 1989. - Vol. 136 - N9. - p.61.

[10] Rumyantsev V.A., Levchenko A.B., Oil spills in the Baltic Sea or why has the crash of the TERN tanker in 2001 led to the same sad results, as accident of the ANTONIO GRAMSCI tanker in 1987 (in Russian - В. А. Румянцев, А.Б. Левченко, Нефтяные разливы в Балтийском море или почему авария танкера "TERN" в 2001 году привела к тем же печальным результатам, что и авария танкера "АНТОНИО ГРАМШИ" в 1987 году)// http://www.limno.org.ru/win/eco.htm (17.03.04)

[11] Krasavin A.P., Vesnin N.M. - Problems of combating emergency oil spills of oil. - Fuel and energy complex (in Russian - А.П.Красавин, Н.М.Веснин. - Проблемы борьбы с аварийными нефтяными разливами нефти. - Топливноэнергетический комплекс). №. 3, 2000, pp.102-103.

[12] Tuzova A.M., Fadeev V.V., Rasnetsov L.D., Rasnetsova B.E. Magnetoactive sorbents on the basis of natural and synthetic zeolites (in Russian - A.M. Тузова, В.В. Фадеев, Л.Д. Раснецов, Б.Е. Раснецова. Магнитоактивные сорбенты на основе природных и синтетических цеолитов)//http://sciteclibrary.ru/rus/catalog/pages/1559.html. Patent-Russian Federation No. 2061540.

[13]Mechkovsky S.A., Lesnikovich A.I., Vorobyov S.A., Zanevskaya Y.V., Kozyrevskaya A.L., Molotok E.V. Highlydisperse magneto-extracted sorbents//Bulletin of Belarusian State University (in Russian - Мечковский С. А., Лесникович А.И., Воробьева С.А., Заневская Ю.В., Козыревская А.Л., Молоток Е.В. Высокодисперсные магнитоизвлекаемые сорбенты // Вестн. Белорус. Гос. Ун-та). Series 2 1998, No. 3, pp.13-16, 79

[14]Filippov V.I.; Dobrinsky E.K.; Malashin S.I.; Safonov A.P.; Lenskaya G.A. Powdery sorbent for collecting petroleum, oils and other hydrocarbons (in Russian - Филиппов В.И.; Добринский Э.К.; Малашин С.И., Сафонов А.П.; Ленская Г.А. Порошкообразный сорбент для сбора нефти, масел и других углеводородов) http://www.ntpo.com/patents_water/water_1/water_1265.shtml/ / Patent-Russian Federation 2088534.

[15]Ferromagnetic sorbent and the device for collecting oil products from the water surface / Ershov O.L., Zhigalin G.Y., Blochin D.Y., Ivanov P.K., Filippov V.I., Makhlin R.S., Moshechkov N.G. (in Russian - Ферромагнитный сорбент и устройство для сбора нефтепродуктов с водной поверхности / Ершов О.Л., Жигалин Г.Я., Блохин Д. Ю., Иванов П. К., Филиппов В.И., Махлин Р.С., Мошечков Н.Г.)// http://magneticliquid.narod.ru/autority/011.htm

[16] Research of receiving an iron ore concentrate for water purification from oil/ Khotynyuk S.S. (in Russian Исследование получения железорудного концентрата для очистки воды от нефти/ Хотынюк C.C.) $/ /$ http://kulibin.org/projects/show/3112/

[17] Mironov V. New Areas for Application of Iron Powders. Works of the 3rd international conference "Materials and Coverings in Extreme Conditions" (in Russian - ), Crimea, Ukraine, September 2004, pp.530-531.

[18]Mironov V., Lapkovskis V., Zemčenkovs V. Sorbent for collecting oil products. Patent of the Republic of Latvia (in Latvian - Sorbents naftas produktu savākšanai. LR patents) LV 13927 B 20.08.2009, Int. Cl. B01J20/02.

[19]Dao, HV, Ngeh, LN, Bigger, SW, Orbell, JD 2004, "The use of magnetic particle technology in the cleansing of oiled birds", Abstract, Proceedings (on a CD Rom) of the workshop on Improving Oiled Wildlife Preparedness and Response in Australia, Australian Maritime Safety Authority (AMSA), Australia. Brisbane, Australia, 18 February 2004.

[20] Orbell, JD, Dao, HV, Ngeh, LN, Bigger, SW 2005, "Magnetic particle technology in environmental remediation and wildlife rehabilitation", Proceedings of the 9th Annual Environmental Postgraduate Conference, Hobart, Australia, 29 Nov- 2 December, 2005, pp.1-7.

[21] Gurevich D. Nefteklin - magnetic collector-sorbent for removal of oil spills from the water surface and from firm surfaces (in Russian - Д.Гуревич. Нефтеклин-магнитный собиратель-сорбент для удаления нефтяных разливов с поверхности воды и с твёрдых поверхностей). www.ntpo.com.

[22] Azizov A.A. Alosmanov R. M., Buniyat-zade I.A., Magerramov A.M., Mamedov G.G. Magnetic sorbent for removal of thin oil films // Environmental Problems of Chemistry and Chemical Technology (in Russian - Азизов А.А., Алосманов Р.М., Буният-заде И.А., Магеррамов А.М., Мамедов Г.Г. Магнитный сорбент для удаления тонких нефтяных пленок // Экологические проблемы химии и химической технологии). 2010, Vol. 53, No. 4, pp.114-117.

[23] Mironovs V., Belovs V., Zemčenkovs V. Equipment for collecting spilled oil products. Patent of the Republic of Latvia (in Latvian - Iekārta izlietu naftas produktu savākšanai. LR patents) LV 13911 B 20.08.2009, Int. Cl E02B15/04.

[24] Summers, M., Aulton, M.: Pharmaceutics. The Science of Dosage Form Design, 2nd Edition, Montford University, Churchill Livingstone, Leicester, 2001. 